\title{
English Participial Adjectives and Arabic Agentive and Patientive Nouns
}

\author{
Khalil Hasan Nofal \\ Department of English/ Language Centre, Philadelphia University, Jordan \\ Email: nofalk48@yahoo.com; knofal@Philadelphia.edu.jo
}

\begin{abstract}
This paper is intended to conduct a fairly detailed contrastive linguistic analysis of the English participial adjectives: present participle and past participle, and their Arabic counterparts, namely, ?ismulfā9il/ agentive noun or active participle, and ?ismulmaf9ūl / patientive noun or passive participle. The process of contrast will be based on morphological, syntactic and semantic criteria. The analysis carried out in the study aims at investigating and scrutinizing, and exploring and revealing any points of convergence and / or divergence in the linguistic behavior of both English and Arabic participials. The paper falls into three sections. The first section incorporates a detailed analysis of the English participial adjectives: present participle and past participle in terms of morphological, syntactic and semantic perspectives. The second section is concerned with their Arabic counterparts: ?ismulfā9il / agentive noun , and ?ismulmaf9ūl / patientive noun in terms of the above mentioned perspectives. The third section is devoted to any possible conclusion that may be arrived at through an overall contrastive analysis of both English participial adjectives and their Arabic counterparts.
\end{abstract}

Index Terms - present participle, past participle, agentive noun, patientive noun, active participle, passive participle

\section{ENGLISH PARTiCipial AdJeCtives}

\section{A. Morphological Perspective}

English makes use of two participle forms; the-ing participle, also known as the present participle, and the -ed participle, or alternatively, the past participle. The-ing participle is derived by adding the -ing suffix to the base form of the verb, that is, base+ing, such as: interest - an interesting story, win - a winning team , and tire - a tiring exercise .The-ed participle, which is sometimes called the -en participle, is produced by adding the $(\boldsymbol{e}) \boldsymbol{d}$ suffix to the base form of the verb, viz, base+ed such as :interest - interested applicants, defeat - a defeated army, and close - a closed shop. On the other hand, the - ed suffix has a variety of morphological realization with irregular / strong verbs. This might be the reason why some linguists refer to it as the -en participle. Following are some examples of irregular past participles, which are derived by ablating: break - a broken window, lose-lost property, and freeze-frozen meat.

The greatest majority of English participles are deverbal, i.e, derived from verbs. However, a few are derived from nouns: appetite - appetising food, neighbour - neighbouring villages. See (Downing and Locke, 1995, P.515) and (Noonan, 1994, P.172).Moreover, it is not uncommon to derive the - ed participles from nouns, especially when there is no corresponding verb. Such participles are called denominal,and some of them are: a cleft - a clefted sentence, a talent - a talented child, and a beard - a bearded man. In addition, a few -ed participles can assume two different morphological realizations depending on whether the participle is used attributively or predicatively, (Close, 1979, P. 87). This can be seen in the following examples:

\begin{tabular}{|l|l|}
\hline Attributive & Predicative \\
\hline a sunken skip & The ship is sunk. \\
\hline molten lava & The lead is melted. \\
\hline a clean- shaven man & His beard is shaved. \\
\hline the drunken men & The men are drunk. \\
\hline my blest father & I am blessed if I know. \\
\hline
\end{tabular}

As regards compounding, some participles can occur compounded with an adverb, an adjective , a noun, or a preposition. These compound structures with participles are common before nouns as can be seen below (Swan 1996, P. 405):
a well-built road
a fast-growing tree
a good-looking boy
a blue-eyed girl
a home-made cake
a flesh-eating animal

$$
\begin{aligned}
& =(\operatorname{adv}+\text {-ed participle }) \\
& =(\operatorname{adv}+- \text { ing participle }) \\
& =(\text { adj }+ \text {-ing participle }) \\
& =(\text { adj }+ \text {-ed participle } / \text { nominal }) \\
& =(\text { noun }+ \text {-ed participle }) \\
& =(\text { noun }+ \text { ing participle })
\end{aligned}
$$


the above-mentioned point

$$
=(\text { prep. }+ \text {-ed participle })
$$

\section{B. Syntactic Perspective}

(Quirk et al, 1991, P.402-3) mention the following four features as characteristics of adjectives: (i) free occurrence in attributive position, (ii) free occurrence in predictive position, (iii) intensification with "very", and (iv) admissibility of comparison. See (Kaplan, 1989, P. 115), (Downing and Locke, 1995, P. 512-519), and (Aarts, 1997, P. 31). Now, to judge at the adjectival status of English participles, let us apply the above tests to two participles; interesting and tired:

a. Attributive position:

1. She told me an interesting story.

2. The tired man went to bed early.

b. Predicative position:

3. Her story was interesting.

4. The man seems tired.

c. Intensification with "very"

5. It was a very interesting story.

6. He seems very tired when he came back.

d. Admissibility of comparison:

7. Her story was more interesting than yours.

8. He was more tried than I expected.

As can be seen in the above examples, the application of the aforementioned tests shows that the participles interesting and tired achieve the full status of adjective, i.e -ing and - $\boldsymbol{e d}$ participles can be used like adjectives (Swan, 1996, P.403).They function both as modifiers and complements. These participial adjectives can be graded. See (Downing and Locke, 1995, P. 514). However, with the participles closed and missing, some of the above tests do not apply. Consider the following examples:

a. Attributive position:

9. She could not find the missing jewels.

10. They were arrested in a closed area.

b. Predicative position:

11. Her jewels are missing.

12. The shop is closed.

c. Intensification with "very"

13.* The jewels seem very missing.

14.* The shop is very closed.

d. Admissibility of comparison:

15.* The jewels were more missing than she imagined.

16.* The shop was more closed than we thought.

The application of the above tests shows that some participles behave as fully- fledged adjectives, while others display some deficiencies. At the same time, the above examples show that any participle that admits of intensification with "very" admits also of comparison and vice versa. However, adjectives that reject intensification with "very" accept it once they are compounded with an adverb or adjective, but not with a noun. The following examples illustrate the point:

17.* very boiled eggs

18.* a very running stream

19.* a very growing tree. very hard-boiled eggs

a very slowly-running stream

a very fast-growing tree

But it can be argued that it is the adverb rather than the whole compound adjective that is intensified by "very". This relation can be shown in Figure (1) below:

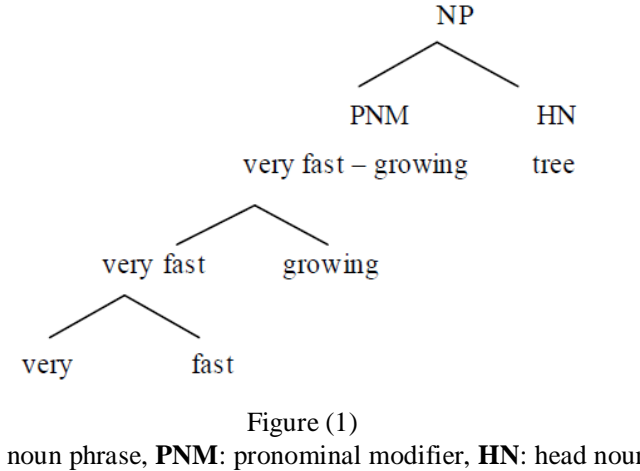


Nevertheless, it might be possible to draw a hazy line of distinction between participles that admit of intensification with "very" and those that reject it. Such a line will enable us to call the former group "descriptive" adjectives and the latter group "classifying" adjectives, (Aarts and Aarts, 1988, P. 68).

Another syntactic feature of English adjectives in general is that they typically occur before the nouns they modify. This is also typical of participial adjectives in general. However, there are cases when an - ed participle must occur in postnominal position, (Quirk et al, 1991, P. 1329). This is the case when the -ed participle is followed by a byagent/actor phrase or by other prepositional construction only post-modification is possible. See (Noonan, 1994, P. 172). Thus we have "the defeated army", the offended man are acceptable but:

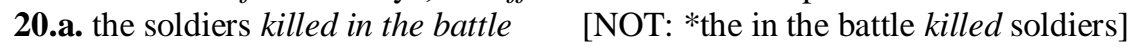

21.a. the books published by Longman [NOT: *the by Longman published books]

22.a. the man offended by the policeman [NOT: *the offended by the policeman man]

But it is possible to think of these adjectives as remnants of reduced relative clauses. That means we often use participles after words in order to define or identify the nouns in the same way we use identifying relative clauses, (Swan, 1996, P.474) and (Roberts, 1998, P. 252).

20.b. the soldiers who were killed in the battle

21.b. the books which were published by Longman

22.b. the man who was offended by the policeman

In addition, some - en participials can occur in both pre-nominal and postnominal positions, but with a different meaning in either case, (Quirk el al, 1991, P. 1330). Consider the following examples:

23. a. the teacher concerned $\quad=$ the teacher in question

b. his concerned look $\quad=$ his worried look

24. a. the jobs wanted = the jobs wanted by individuals

b. the wanted man $\quad=$ the man wanted by the police

From a morpho-syntactic point of view, participial adjectives behave in a manner identical to that of adjectives proper. This is seen in the fact that the morphological form of a participial adjective is invariable regardless of the number, gender or case of the noun it modifies. This is illustrated in the following examples:
25. a. a recorded talk VS
b. a dying man vs
* some recorded $\underline{\mathbf{s}}$ talks
a dying woman

Another morpho-syntactic consideration related to participial adjectives has to do with the transitivity or intransitivity of the verb from which the participial adjective is derived. From the fact that an -ing participle has an active meaning, while the - ed participle has a passive meaning, (Quirk et al, 1991, P.413), it follows that the -ing participle can be derived from both transitive and intransitive verbs, whereas the derivation of an -ed participle is restricted to transitive verb. Or to put it straight, an intransitive verb typically yields an -ing participle, while a transitive verb can yield both ing and - $\boldsymbol{e d}$ participle adjectives. Here are some illustrative examples:
26. a. The man is dying
b. ${ }^{*}$ He is died
He is a dying man
*He is died man
27. a. The creature lives
b. *the creature is lived.
(vi) It is a living creature
*It is a lived creature
28. The tale excited the children
(vt) It is an exciting tale.
The tale is exciting.
The excited children would not go to bed.
The children were excited.

But the above restrictions on intransitive verbs do not apply across the board. In fact, some intransitive verbs can yield -ed participial adjectives. In such cases, the passive interpretation is impossible, (Swan, 1996, P,404). The following sentences exemplify the point:
29. The prisoner escaped.
30. The flower has faded.
(vi) the escaped prisoner
(vi) the faded flower
31. The general retired.
(vi) the retired general
32. A leaf has fallen.
(vi) a fallen leaf

But this should not be taken to mean that such verbs do not yield -ing participial adjectives. In fact, they do, and in such cases, the -ing participial adjectives refers to process, while its - ed counterparts refer to a state or result. See (Downind and Locke, 1995, P. 454). This point is illustrated in the following examples:

33. a. The child is growing.

b. The events are coming.

34. a. The man has grown up.

b. The leaves had fallen.

It is a growing child. (process)

The coming events may be bad. (process)

He is a grown up man. (state)

They are fallen leaves. (result)

On the other hand, the -ing and the - ed forms do not always have an adjectival status. Very often, their status is verbal or nominal. For the -ing form the verbal status is unquestionable when the form is followed by a direct object , (Quirk el al, 1991, P.414). Thus the -ing forms in the following examples have a verbal function:

35. His remarks are insulting us. 
36. You are horrifying the children.

With the - $\boldsymbol{e d}$ forms, the verbal force is explicit when there is by - agent / actor phrase with a personal object, (Quirk el al, 1991, P.413). This point can be seen in the following examples:

37. She was rewarded by her boss.

38. He was seen off by everybody.

But both the -ing and he - $\boldsymbol{e d}$ forms achieve an adjective statue when intensified by "very" as exemplified in the following sentences:

39. His remarks are very insulting.

40. She looks very tired today.

It follows that the presence of "very" together with explicit indicator of verbal force would produce an unacceptable sentence, (ibid). This is why the following sentences are ill -formed:

41.* You are very horrifying the girls.

42.* She was very rewarded by her boss.

But with the - $\boldsymbol{e d}$ participle, there is an increasing tendency towards the acceptance of the co-occurrence of "very" together with a by -agent / actor phrase having a personal agent. (ibid: 415) Here are two examples:

43. The man was very offended by the police.

44. She is very much appreciated by everybody.

It is not out of place to state that the participle sometimes reaches full adjective status when it is compounded with another element (ibid).See (Quirk et al, 1972, P. 245).

45. The eggs are boiled hard

46. The news are breaking my heart

47. The girl is looking good.

The eggs are (very) hard - boiled.

They are (very) heart - breaking news.

She is a (very) good-looking girl.

That is to say many participial adjectives are compounded with a noun as can be seen in the above examples. Pseudoparticipial adjectives can also be compounded: a fair-haired child, a four-footed animal. In these cases, the pseudo participle cannot be used alone:* a haired child,*a footed animal .See (Downing and Locke, 1995,P.516).

\section{Semantic Perspective}

In the above section, it has been pointed out that both transitive and intransitive verbs can produce -ing participial adjectives, whereas typically only transitive verbs can produce - $\boldsymbol{e d}$ participial adjectives. This morpho-syntactic feature has very significant semantic correlations. The -ing participial adjective is active in meaning, whereas the -ed participle form gives a passive meaning. (Swan, 1996, P.404):

48. falling leaves $=$ leaves that fall

49. a meat-eating animal $=$ an animal that eats meat.

50. she walks out smiling $=$ She was smiling.

51. a broken heart $=$ a heart that has been broken

52. he lived alone, forgotten by every body. = He had been forgotten by everybody.

A further semantic extension of the above distinction is that the -ing participial adjective has an agentive reference, while its - $\boldsymbol{e d}$ counterpart has a patientive reference. The semantic role of each type of participle can be stated in the following terms:

1). The present participle adjective modifies a referent that is the agent of the verb from which this adjective is derived. Thus, we say:

53. tiring exercise

54. surprising incident

The exercise tires me.

The incident surprises me.

because transformationally, the nouns exercise and incident functions only as the agent of the verbs tire and surprise.

2). The past participle adjective modifies a referent that is the patient of the verb from which the adjective is derived. Thus we say:

55. a broken window

56. the boiled egg

$\mathrm{X}$ broke the window.

Someone boiled the egg.

because we expect somebody or something to have broken the window, and someone to have boiled the egg. In other words, we expect the window and the egg to have been affected by the action, rather than having affected it. But it has also been pointed out in the pervious section that some intransitive verbs can produce past participle adjectives with active meaning (Swan, 1996 ,P.404), although this is not the norm. It is not unusual to come across expressions like the following:

57. a the vanished civilization

58. a the retired general

59. a the grown up daughter

60. a the escaped prisoner

61. a the developed countries

In such cases, the semantic relationship between the past participle and the head noun is reversed. The past participle now assumes an agentive rather than a patientive role towards the head noun. This can be seen in the following paraphrases that can be postulated for the above expressions: 
57. b. the civilization that (has) vanished

58. b. the general who (has) retired

59. b. the daughter who (has)grown up

60. b. the prisoner who (has) escaped

61. b. the countries that have developed

The same exception applies to those very few cases in which a present participle adjective is used to modify a noun that is related to it patientively. Consider the following examples:

62. a losing battle a battle that we (have) lost

63. the missing jewels the jewels that she (has) missed

In these examples, the head nouns, battle and jewels, hold a patientive relationship to their premodifying participle, losing and missing respectively.

Past participles used as adjectives are used to say how people feel,(Swan, 1996, P. 404) and (Eastwood, 1992, P.194):

64. I was very interested in the lesson [NOT: I was very interesting in the lesson.]

65. I didn't enjoy the party because I was bored. [NOT: ... because I was boring.]

The present participles interesting and boring and the like describe people or things that cause the feelings. Compare:

66. She is an interesting writer, and I am very interested in her novels.

67. Boring teachers make bored students.

From a syntactic-semantic point of view, many adjectives have a form identical to participles .The rule of thumb in distinguishing adjectives from participles is as follows: "If the form has a verb which corresponds to it in meaning, it is a participle, if it does not, it is an adjective." ( Noonan ,1994, P.173) Consider the following examples:

68. a. a retired salesman [participle]

b. an unexpected decision [adjective ]

c. a calculating machine [participle]

d. a calculating person [adjective]

Retired corresponds to a verb retire, so it is a participle. Unexpected, however, has no corresponding verb *unexpect, so it is an adjective. Calculating does have a corresponding verb, calculate, but only in calculating machine does the meaning of the form in -ing correspond to the meaning of the verb. In calculating person, there is no such correspondence, so here calculating is an adjective. In calculating machine, it is a participle.

\section{Arabic Agentive And Patientive Nouns (?iSMUlfā9il) And (?ISMUlmaf9ūL)}

\section{A. Morphological Perspective}

Arabic equivalents of English present and past participle adjective are known as ?ismulfäail and ?ismulmaf $9 \overline{\boldsymbol{u}} \mathbf{l}$ respectively. The former is often referred to as agentive noun, and the latter as patientive noun. Each of these Arabic forms has two different morphological realizations depending on whether the root verb from which each form is derived is trilileral or multiletiral. Because of the fact that Arabic morphological processes are generally nonconcatenative, it would be more adequate to describe the morphology of ?ismulfā9il and ?ismulmaf9ūl in terms of the prosodic template model as suggested by, (Katamba ,1993, P.166). Following is a description of the morphological derivation of the above two forms by means of the prosodic template. (Rajhi, 1973, P. 75-84), (Maghalseh, 2007, P.521-532).

1). With roots of three consonants, also called triliteral, ?ismulfä $9 i l$ is derived by adding a discontinuous morph made of $\mid \bar{a} /$ inserted after the first consonant in the root, and $/ i /$ before the final consonant, if the verb is sound e.g: Өalam-a (oppress) becomes $\theta$ ālim (oppressor), jạal-a (create)becomes jạ̄̂il (creator).

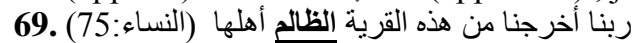

70. إني جاعل في الأرض خليفة (البقرة : (30)

If the verb is hollow, a verb of which the second radical is (?alif), the agentive noun (?ismulfā9il) is derived by changing its second radical (?alif) into (hamzah), e.g. qām-a (stood) becomes qā?im (the one who is standing). If the second radical is (hamzah), it remains as it is e.g.: sa?al-a (asked) becomes sā?il (questioner) .

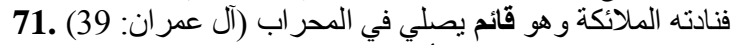

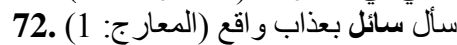

If the verb is defective, a verb of which the third radical is ( $w \bar{a} w)$ or $(y \bar{a} ?)$, the agentive noun is derived by inserting $/ \bar{a} /$ after the first radical and deleting the third radical, $(y \bar{a} ?)$, in the nominative and genitive cases, and keeping it in the accusative case. The following are illustrative examples respectively: baqiya (endure) becomes bāq-in (the thing that will endure), baghā (willfully disobey) becomes bāgh-in (the one who willfully disobeys), and $\theta$ awā (dewel) becomes $\theta$ āw-in (dweller).

73. ما عندكم ينفذ وما عند اله باقى (النحل :

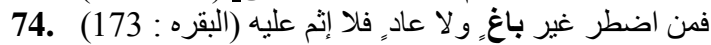

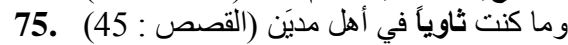

With the same class of verb, ?ismulmaf $9 \bar{u} l$ is derived by a discontinuous morph consisting of /mal attached before the first constant in the root, and / $\overline{\mathrm{u}} /$ before the last consonant, if the verb is sound e.g. ?akal-a (eat up) becomes ma?kūl (eaten up) ba $\theta$-a ( scatter about ) becomes mab $\theta \bar{u} \theta$ (scattered about) .

76. فجعلهم كعصف مأكول (الفيل : (5) () 
77. يوم يكون الناس كالفراش المبثوث (القار عة : 4) 1)

If the verb is hollow, it is changed into present form and the present marker ( $y \bar{a}$ ?) is changed into (mīm), e.g: Iām-a (blame) becomes malūm (blameworthy).

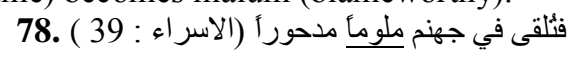

If the verb is defective, it is also changed into present form and the present marker ( $y \bar{a}$ ?) is changed into ( $m \bar{m} m)$ and the final vowel ( $w \bar{a} w)$ is geminated, e.g. : raj-a (hope) become marjū ( the one who is hoped).

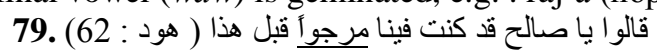

The two processes are shown in Figures (2) and (3) below:

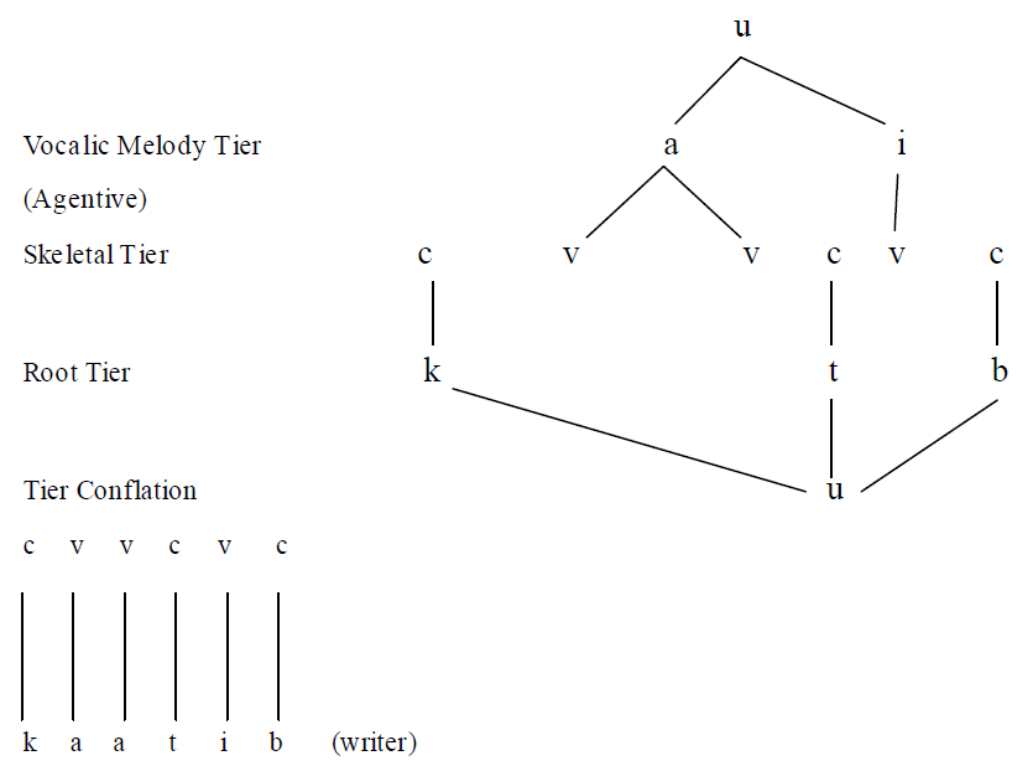

Figure (2)

Patientive Morpheme Tier

Vocalic Melody Tier

Skeletal Tier

u

Root Tier

Tier Conflation

c v c c v v c

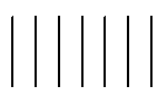

$\mathrm{m} \mathrm{a} \mathrm{k} \mathrm{u} \mathrm{u} \mathrm{b} \mathrm{(something} \mathrm{that} \mathrm{is} \mathrm{written)}$

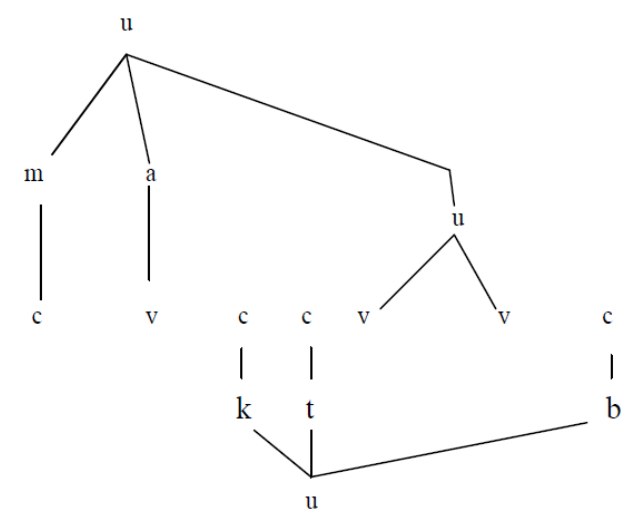

Figure (3)

Figure (2) represents the prosodic template for the the derivation of ?ismulfā9il (kātib) from the triconsonantal root (ktb). Figure (3) shows the prosodic template for the derivation of ?ismulmaf9ūl (maktūb) from the same triconsonantal root.

2. Verbs of multiliteral roots produce different morphological forms of ?ismulfā9il and ?ismulmaf9ūl. With such verbs the discontinuous agentive morph consists of $/ m u /$ added before the first constant of the root, and $/ i /$ inserted immediately before the final consonant of the root, e.g. ?axraj -a (brings forth) becomes muxrij (the one who brings forth).

80. واله مخرجّم ما كتنم تكتمون (البقره :72)

The patientive morph consists of $/ m u /$ prefixed to the first consonant in the root, and $/ a /$ inserted before the final consonant of the root, e.g. ?axraj -a (cast out ) becomes (muxraj) (be cast out).

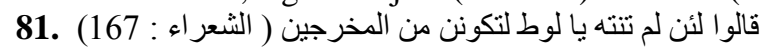

Figures (4) and (5) below illustrate this point: 


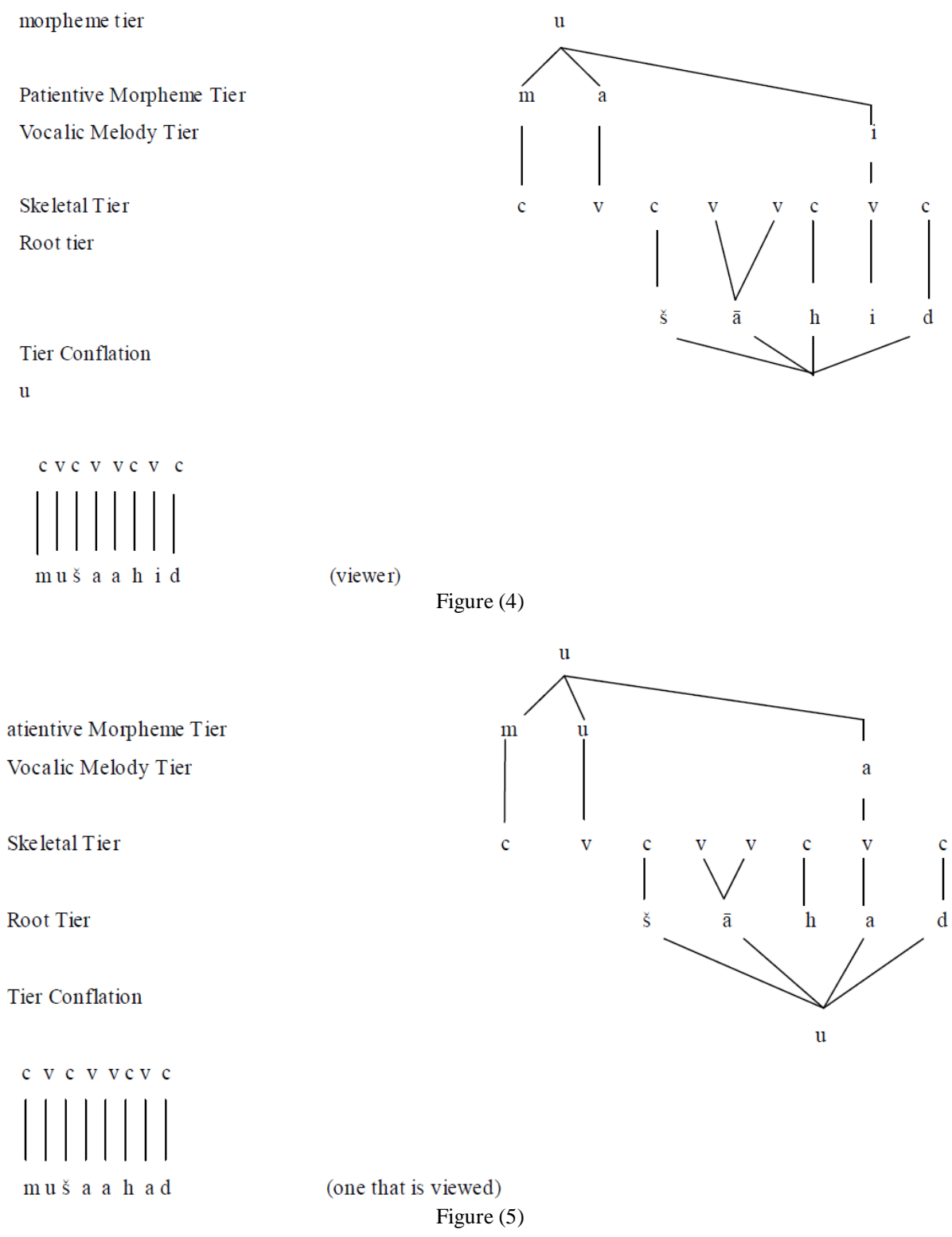

Figure (4) shows the prosodic template for the derivation of ?ismulfā9il (mušāhid) "viewer" from the quadriliteral root (šāhad-a), whereas figure (5) shows the prosodic template for the derivation of ?ismulmaf9ūl (mušāhad) "the one that is viewed" from the same quadriliteral root.

With some verbs of multiliteral roots, both ?ismulfā9il and ?ismulmaf9ūl can assume the same morphological form, (Rajhi,A, 1973, P.83) and (Afaghni, S, 1081, P.198-208) The meaning can be recovered from the context. This is especially the case when the penultimate sound in the multiliteral root is $/ \bar{a} /$ and the verb is transitive, as in the following examples:

82. ?ixtāra - muxtār : (lit) = chooser / something chosen

83. ?ightāba - mughtāb : (lit) = gossiper / someone gossiped

With some triconsonantal verbs, it is possible, semantically, for ?ismulmaf9 $\bar{u} l$ to have the alternative form fa9ill, as in the following examples:
84. qatala -
maqtūl / qatīl -
(killed)
85. jaraћa -
majrūh / jarīh -
(wounded)

\section{B. Syntactic Perspective}

From a morpho-syntactic point of view ?imulfā9il and ?ismulmaf9ūl show full agreement in number, gender, case, and definition with their referents, especially when the referent is personal or non personal noun, ( Humuz, 1993, P.68 - 84) and (Afghani, 1981, P.198-208) as the following examples illustrate:

- Agentive Noun:

86. a هو الخالق البارئ المصور له الأسماء الحسنى (الحشر:24)

(definite, nominative, masculine, singular) 


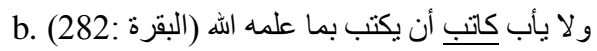
(indefinite, nominative, masculine, singular)

c. السارق و السارقة فأقطعوا ايديهما جز اءً بما كسبا ( المائدة : (38) ) (definite, nominative, masculine, singular)

d. لا عاصم اليوم من أمر اله ( هود:43) (indefinite, nominative, masculine, singular)

e. ربنا أخرجنا من هذه القرية الظالم أهلها ( النساء : (15) (definite, dative, masculine, singular)

f. مثردون الى عالم الغيب و الثهادة (التوبة : (indefinite, dative, masculine, singular)

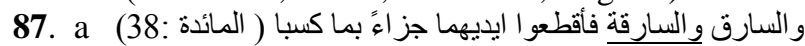
(definite, nominative, feminine, singular)

b. كل نفس ذائقه الموت ( الأنبياء : (indefinite, nominative, feminine, singular)

c. ما كنت قاطعة أمرآ حتى تشهدون (النحل:32) (indefinite, accusative, feminine, singular)

d. يوم تذهل كل مرضعه عما أرضعت ( الحج:2) (indefinite, dative, feminine, singular)

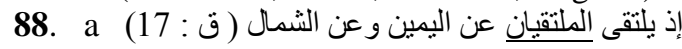
(definite, nominative, masculine, dual)

b. قالوا ان هذان لساحر ان (طه :63) (indefinite, nominative, masculine, dual)

c. بل يداه مبسوطنان ( المائدة : (indefinite, nominative, feminine, dual)

d. وسخر لكم الثمس والقمر دائبين ( ابر اهيم :macculine (indefinite, accusative, masculine/ feminine, dual)

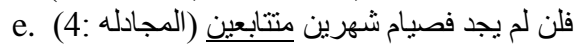
(indefinite, dative, masculine, dual)

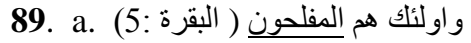
(definite, nominative, masculine, plural)

b. بل هم قوم طاغون (الذاريات : (indefinite, nominative, masculine, plural)

c. وكنا نحن الوارثين (القصص: 58) (definite, accusative, masculine, plural)

d. كونو قردة خاسئين (البقرة :65) (indefinite, accusative, masculine, plural)

e. فبح بحمد ربك وكن من الساجدين (الحجر : 98) (definite, dative, masculine, plural)

f. وما هم بخارجين من النار ( البقرة : (167) (indefinite, dative, masculine, plural)

90. a فالصالحات قانتات حافظات للغيب (النساء : (definite, nominative, feminine, plural)

b. هل هن كاشفات ضره ( الزمر : (indefinite, nominative, feminine, plural)

c. ليدخل المؤمنين و المؤمنات , جنات تجري من تحتها الأنهار (الفتح : 5) (الفات ) (definite, accusative, feminine, plural)

d. والنخل باسقات لها طلع نضيد (ق :10) (indefinite, accusative, feminine, plural)

e. فالمدبر ات أمرا (الناز عات : 5) (definite, dative, feminine, plural)

\section{- Patientive Nouns:}

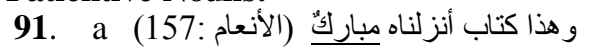
(indefinite, nominative, masculine, singular)

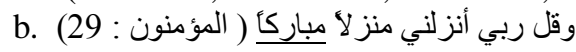
(indefinite, accusative, masculine, singular)

c. الى يوم وقت معلوم (الحجر : (definite, dative, masculine, singular)

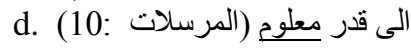
(indefinite, dative, masculine, singular)

92. a وقالت اليهود يد الله مغلولة (المائدة :64) 
(indefinite, nominative, feminine, singular)

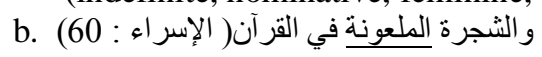
(definite, accusative, feminine, singular)

c. ولئن أخرنا عنهم العذاب الى أمة معدودة (هود : 8) (indefinite, dative, feminine, singular)

93. a إذ المجرمون ناكسو رؤوسهم (السجدة : 12) (definite, nominative, masculine, plural)

b. وإن كلّ" لما جميع لدينا محضرون (يس : 53) (indefinite, nominative, masculine, plural)

c. وترى المجرمين يومنذٍ مقرنين في الأصفاد(إبر اهيم : 49) (indefinite, accusative, masculine, plural)

d. قال انك من المنذرين (الأعراف :10)

(definite, dative, masculine, plural)

94. a و و المحصنات من النساء (النساء : (25)

(definite, nominative, feminine, plural)

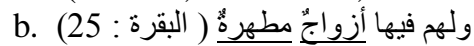

(indefinite, nominative, feminine, plural)

c. جنات عدن مفتحة لهم الأبو اب (ص : (indefinite, accusative, feminine, plural)

d. يوم يكون الناس كالفر اش المبثوث (القار عة :

(definite, dative, feminine, plural)

From a functional point of view, the two forms, ?ismulfä9il and ?ismulmaf9ūl, can realize three functions; modificational, nominal and adverbial, as follows:

a. Modificational: Here the two forms function as pre-nominal modifier and post-nominal modifiers typically following their referents:

95. ربنا"أخرجنا من هذه القرية الظالم أهلها (البقره : pre - nominal modifier

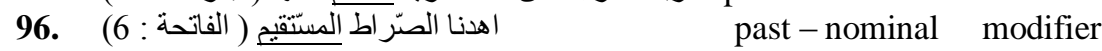

b. Nominal: Here the two forms are capable of realizing almost any function that is typically realized by noun:

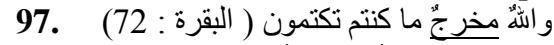 (subject complement)

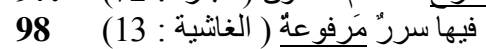

(subject complement)

c. Adverbial: The typical adverbial function that the two forms can realize is that of manner adverbial; as the following examples show:
99.
(manner adverbial)

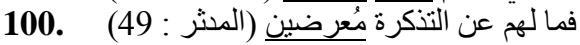

(manner adverbial)

The two forms, ?ismulfā9il and ?ismulmaf9ūl can be derived only from verbs. The former can be derived from both transitive and intransitive verbs, whereas the latter is derived only from transitive verbs, as can be seen in the following examples:

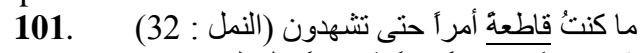

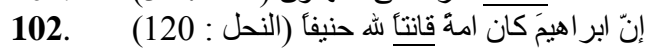

103.

With respect to complementation, ?ismulfä9il and ?ismulmaf9ül behave in the same manner as their corresponding verbs. This means that ?ismulfāgil that is derived from a transitive verb can have a direct object, and even an indirect object if the verb is ditranstive. Consider the following examples:

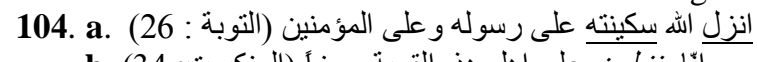

b. انئا منزلون على الهل هذه القرية رجزأ (العنكبوت:

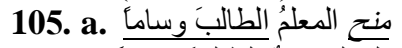

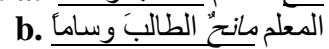

In sentence (104.b) above, the underlined noun زمرأ functions as direct object of the italicized agentive noun منزلون In sentence (105.b) the underlined nouns وساما function respectively as indirect object and direct object of the italicized agentive noun مانح . This transitivity is not possible for those forms of ?ismulfä9il that are derived from intransitive verbs. Such forms do not take any object, as can be seen in the following example:

106.a. هربَ الطفلُ

b. الطفلُ هاربُ

As far as ?ismulmaf9ül is concerned, it has the function of its passive verb. This means that ?ismulmaf9ūl that is derived from a transitive verb can have a pro-agent :

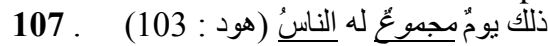

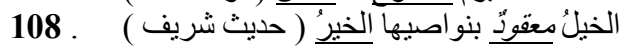

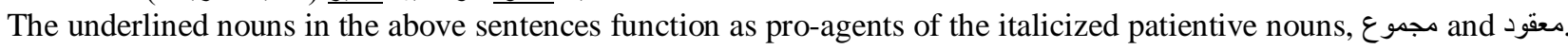


As pointed out above, ?ismulfā9il and ?ismulmaf9ūl agree with their referents in terms of number, gender and case. In fact, this statement needs some modification. Adjectives referring to qualities that are exclusively characteristics of females may not show agreement in gender with their referents. Consider the following examples:

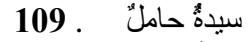

110. إمر أهُ عاقرّ"

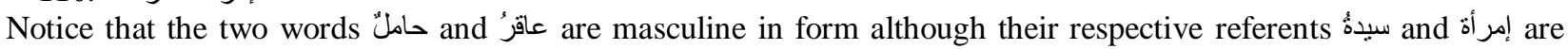
feminine. This is because the qualities of pregnancy and infertility are characteristics of women.

\section{Semantic Perspectives}

When used as postnominal modifiers, ?ismulfā9il and ?imulmaf9ūl display a high degree of semantic regularity. The former modifies a referent that is invariably the agent of the verb from which ?ismulfä9il itself is derived. The latter, i.e. ?ismulmaf $9 \bar{u} l$ modifies a referent that is the patient of the verb from which ?imulmaf9ül itself is derived. In other words, there is a consistent agentive relationship between ?ismulfä9il and its referent in the same way that there is consistent patientive relationship between ?ismulmaf9ūl and its referent, (Zamakhshari, P. 230), (Ibn Ya?ish, 6, P. 80), (Al- Istrabadi, 1985, P.2: 203) and (Samaira'i, 1981, P. 59) These interpretations can be seen in the following examples:

111. السب قاتلّ"

112. الشبالك مكسور"

In sentence number (111) the noun السم is from which the italicized ?ismulfā9il, (قايل), is derived. Similarly, in sentence number (112) the noun الشباك is transformationally the patient of the verb كسر from which ?ismulmaf9ūl, (مكسور) is derived. These distinctive semantic relationships holding between the above underlined head nouns and their postnominal modifiers, i.e. ?ismulfā9il and ?ismulmaf9ūl, are not influenced by the number of letters / consonants found in the root verb from which the postnominal modifier is derived. Whether the root verb is trilateral or multiliteral, the semantic role played by the head noun towards ?ismulfä9il is that of effecting agent, whereas the role played by the head noun towards ?ismulamf $9 \bar{u} l$ is that of effected patient. The above labeling of ?ismulfā9il as agentive noun, and ?ismulmaf $9 \bar{u} l$ as patientive noun may not be appropriate when these two forms are used in a modificational function. In fact, in such a function, it is certainly more appropriate to refer to ?ismulfä9il as agentive adjective, and to refer to ?ismulmaf9ūl as patientive adjective.

From another semantic point of view that has morphological correlations, there are a number of forms that are almost semantically equivalent to ?ismulfā9il and ?ismulma9ūl, but which have different morphological realization. One of these forms which is sometimes semantically equivalent to ?ismulfā9il and ?ismulma9ūl is known as صفهه مشبهة (lit. likened adjective). Some of the adjectives that belong to ?ismulfā9il are those that have the morphological forms fa99lān, faglā?, fa9il, and fa9īl :

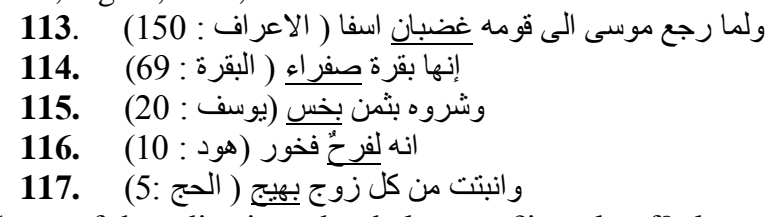

Some of the adjectives that belong to ?ismulmaf9ūl are some of those that have the morphological form fa9īl, such as فريح (kounded). Other forms that may assume the semantic role of ?ismulfā9il are known by the term (lit. exaggerative form), ( Maghalseh, 2002, P.424) and (Afaghani, 1981, P.198-208). This class may assume various morphological forms, such as fa9il, fa99āl, fa9ūl, mif9āl, and fa9īl. The following are illustrative examples:

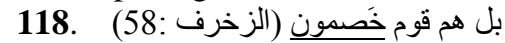

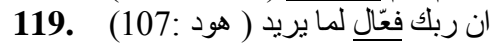

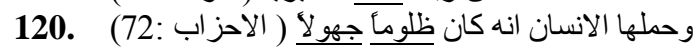

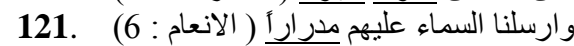

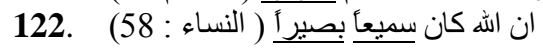

One more point that is worth mentioning is that ?ismulfā9il and ?ismulmaf9ūl indicate pastness, futurity, continuity and durability, (Samira'I, 1981 , P. 51), (Zamakhshari, 4, P. 189), (Zamakhshari , 2 , P.230 ), (Al-Badri,1404, P. 272 \& 308), (Al-Istrabadi , 1985 ,2, P. 198).

(a) Pastness:

123. في الله شكُّ فاطرُ السماو ات و الارض (ابر اهيم :10)

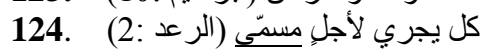

The agentive noun فاطر مستر in sentence (123) indicates pastness to mean فطر (created).Similarly, the patientive noun مستّى (-ed appointed) in sentence (124) indicates pastness to mean(-ed appointed).

(b) Futurity:

125. كل نفس ذائقة الموت (الانبياء : (275) :

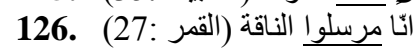

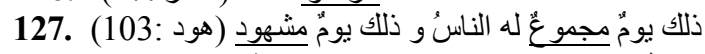

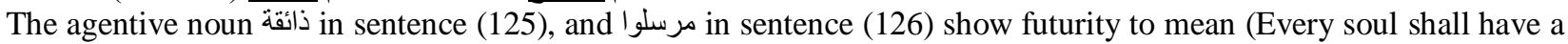
taste of death) and (We will send the she-camel) respectively. The patientive noun مشكود in senten (127) show futurity to mean (a day for which mankind will be gathered : That will be a Day of Testimony). 
(c) Present time:

128. ما لهم عن التذكرة معرضين (المدثر : 199)

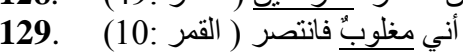

By the same token, the underlined agentive noun معرضين and patientive noun مغلوب indicate present time to mean (They turn away from admonition) and (I am one overcome).

(d) Continuity:

130. انّ الله فالقيُ الحبّ والنوى (الانعام:

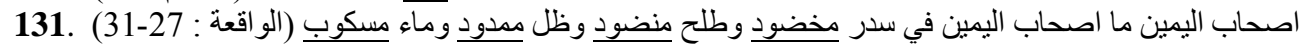

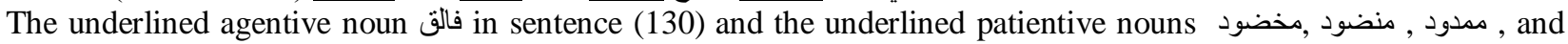
in sentence (131) imply continuity to mean respectively: (It is Allah Who causeth the seed-grain) and (the datestone to split and sprout), (He is that cleaveth the day-break from the dark), (They will be among Lote-trees without thorns, among Talh-trees with flowers piled one above another, in shade long-extended, by water flowing constantly).

(e) Durability:

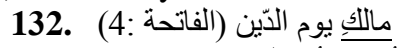

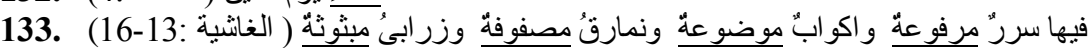

The underlined words in the above sentences indicate duration to mean respectively:(Master of the Day of Judgment. Therein will be couches of dignity raised on high. Goblets placed ready. And cushions set in rows. And rich carpets all spread out).

\section{CONTRASTIVE ANALYSIS}

The following contrastive analysis will be carried out on the three levels of linguistic analysis handled in the two foregoing sections, i.e. the morphological, syntactic and semantic levels. The ensuing contrastive analysis will reveal the extent to which English participial adjectives and their Arabic equivalents, namely ?ismulfä9il and ?ismilmaf9ūl converge and / or diverge in relation to their respective linguistic behavior. However, for convenience, throughout the following sections, the terms agentive noun and patientive noun will be adopted to refer to the morphological forms of ?ismulfä9il and ?ismulmafgül respectively.

\section{A. Morphological Contrast}

There is no similarity at all between the morphology of English participial adjectives and that of their Arabic equivalents. Whereas the derivation of English participial adjectives can be accounted for in terms of concatenative morphology, there is no way of describing the derivation of Arabic agentive and patientive nouns except by means of nonconcatenative morphology using prosodic template model. This is to say that the derivation of English participial adjectives is only a matter of suffixation that does not interfere with the internal phonological structure of the base. But when it comes to Arabic, the derivation of the agentive and patientive nouns relies heavily on vocalic infixation which may sometimes be accompanied by both consonantal and vocalic prefixation. Such a process involves the manipulation of the internal phonological structure of the base in such a way that concatenative morphological models cannot account for.

On the other hand, whereas English makes use of only two morphological forms of participial adjectives, namely, the -ing and the - ed participle forms regardless of the phonological structure of the base, Arabic is more variable in that it allows four different morphological forms of agentive and patientive nouns. In addition, in Arabic, the phonological structure of the base / root is the major factor that determines the morphological form of the agentive or patientive noun. This is evidenced by the fact that the morphological forms of Arabic agentive and patientive nouns that are derived from trilateral roots are completely different from those of their counterparts that are derived from quadrilateral or multiliteral roots.

From inflectional point of view, Arabic agentive and patientive nouns / adjectives have to agree with their referents in terms of number, gender, case and definiteness / indefiniteness. In contrast, English participial adjectives have invariable morphological forms regardless of any concordial aspect.

From a morpho-syntactic point of view, Arabic agentive and patientive nouns are invariably deverbal, i.e, derived from verbs, whereas English participial adjectives are either denominal (derived from noun), or deverbal. From another morpho- syntactic perspective, in Arabic transitive verb can yield both agentive and patientive nouns, whereas an intransitive verb yields only an agentive noun. However, in English there are cases when the - $\boldsymbol{e d}$ participial adjective is derived from an intransitive verb, as in an escaped prisoner or grown man.

\section{B. Syntactic Contrast}

Besides their modificational function, Arabic agentive and patientive nouns can realize the syntactic functions typical of nouns. English participial adjectives tend to display the same kind of behavior, except that they do not realize the function of manner adverbial. This can be seen in the following examples:

134. I don't like the unknown.

(Od)

135. The unknown is interesting

$(\mathrm{S}+\mathrm{Cs})$

136. I found him interesting. 
For Arabic examples, see (95-100) above.

From a systematic point of view, Arabic agentive and patientive nouns usually postmodify their referents. English participial adjectives typically behave in the opposite manner. That is, they premodify their referents. The following examples illustrate the point:

137. قرأت رواية ممنعة.

138. We saw a roaring lion.

With respect to complementation / transitivity, Arabic agentive and patientive nouns behave like their corresponding verbs so that, by extension, Arabic agentive and patientive nouns can be described as transitive or intransitive, (cf - 105 104 above). Contrastively, English participial adjectives that are compounded with nouns have these nouns transformationally as direct object even though the noun precedes the participle. This can be seen in the following example:

139. That animal eats flesh. It's a flesh-eating animal.

\section{Semantic Contrast}

Arabic shows a higher degree of systemacity than English. All Arabic agentive nouns are active in meaning and governed an agentive relationship to their head nouns. Similarly, all Arabic patientive nouns are passive in meaning, and related patientively to the nouns they modify. In English, the situation is marred by some kind of confusion in the semantic roles of participial adjectives. It is sometimes possible for an -ing participial adjective referent to assume a patientive roles, and for the referent of its-ed counterpart to assume an agentive role although the reverse is the typical kind of relationship which each of them usually has with its head noun. The following examples are illustrative of this point:

140. a. We have lost the battle

b. It is losing battle

141. a. The tree has fallen.

b. It is a fallen tree.

In (142.b) the head noun battle is modified by an -ing participle although the noun itself is the patient of the verb lose from which the participle losing is derived. By the same token, in (141.b), the past participle adjective fallen is atypically used to modify the head noun tree which is the agent of the verb fall from which the participle itself is derived.

\section{REFERENCES}

[1] Aarts, B. (1997). English Syntax and Argumentation. Macmilan Press Ltd, London.

[2] Aarts, F and J. Aarts. (1988). English Syntactic Structures .University Press, Cambridge.

[3] Afaghaani. S. (1981). Al-Mujaz fi Qawa@id Al-lughti Al-Arabiyyah. Daar Al Fikr. Beirut -Lebanon.

[4] Badri, K. (1404 H). Al-Zaman fi Al-Nahw Al- Arabi. Daar Ummayya - Al- Riyyadh.

[5] Close, R., A (1979). Reference Grammar. Longman.

[6] Downing, A. and Locke P. A (1995).University Course in English Grammar. Phoenix. ELT, London.

[7] Eastwood, J. (1992). Oxford Practice Grammar. Oxford University Press, London.

[8] Hamouz. A. (1993). Thahirat Al-Taghleeb fi Al- Arabiyyah. Mu'ta University- Jordan.

[9] Ibn Ya'ish,M. (----). Sharh Al- Mufaşal. Al-Muniriyyah Press. Egypt.

[10] Istrabaadi. R. (1985). Sharh Al-Kafiyyah . Daar Al-Kutub Al - Arabiyyah. Beirut -Lebanon.

[11] Kaplan, J. (1989). English Grammar-Principles and Facts. Prentice Hall, inc. New Jersey.

[12] Katamba, F. (1993). Morphology .St. Martin's Press, New York.

[13] Maghalseh, M. (2007). Al-Nahaw Al- Shaafi. Mu'ssasat Al -Risala .Beirut-Lebanon.

[14] Noonan, (1994). M. A Course in English Grammar. Deborah L. Mulvaney.

[15] Quirk, R. etal. (1991). A Comprehensive Grammar of the English Language, New York.

[16] Quirk, R.et al. (1980). A Grammar of Contemporary English. Longman, Hong Kong.

[17] Rajihi,A.(1973). Al-Tatbeeq Al-Sarfi. Daar Al-Nahda Al-Arabiyyah, Beirut -Lebanon.

[18] Roberts, N. (1998). Analysing Sentences-An Introduction to English Syntax. Longman. Ltd, London.

[19] Saamarraa'i, I. (1980).Al-Fi؟lu: Zamanuh wa Abniyatuh. Mu'ssasat Al- Risalah- Beirut -Lebanon.

[20] Saamarraa'i, F. (1981).Ma?aani Al-Abniyya fi Al-Arabiyyah- Kuwait University.

[21] Swan, M. (1996). Practical English Usage. Oxford University Press, London.

[22] Zamakhshari. (-----): Al-Kashsha:f . Daar Al-Ma@rifa. Beirut-Lebanon.

[23] Zamakhshari. (------): Al-Mufassal. Daar Al-Jabal. Beirut -Lebanon.

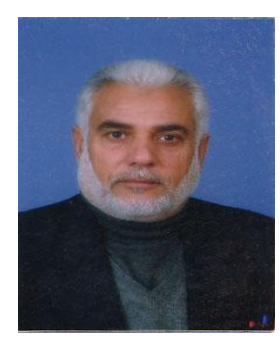

Khalil Hasan Nofal obtained his Ph.D. from Jordan University in 2002. He occupied some educational, administrative and academic posts: School Supervisor (English) EDC. Administration Officer, and General Education Specialist / UNRWA - UNESCO. He is Director Language at Philadelphia University. He is Editorial Board Centre member in (IJSST) and (EJBSS) and APETAU member. 